\title{
Using Minisci Reaction for Modification of the tris-Dioximate Metal Clathrochelates: Free-Radical Substitution at the Glyoximate Fragment of an Iron(II)-Encapsulating Cage Framework
}

\author{
Alexey B. Burdukov, ${ }^{a}$ Mikhail A. Vershinin, ${ }^{a}$ Natalie V. Pervukhina, ${ }^{a}$ \\ Natalie V. Kuratieva, ${ }^{\text {a }}$ Ilia V. Eltsov, ${ }^{\text {b }}$ Alexander S. Belov, ${ }^{\text {c }}$ Yan Z. Voloshin, ${ }^{\mathrm{c}}$ \\ and Andrei A. Nefedov ${ }^{\mathrm{b}, \mathrm{d}}$ \\ ${ }^{a}$ Nikolaev Institute of Inorganic Chemistry SB RAS, 630090 Novosibirsk, Russia \\ ${ }^{\mathrm{b}}$ Novosibirsk State University, 630090 Novosibirsk, Russia \\ ${ }^{\mathrm{c}}$ A.N. Nesmeyanov Institute of Organoelement Compounds RAS, 119991 Moscow, Russia \\ ${ }^{\mathrm{d}}$ N.N. Vorozhtsov Novosibirsk Institute of Organic Chemistry SB RAS, 630090 Novosibirsk, Russia \\ @Corresponding author E-mail: lscc@niic.nsc.ru
}

\begin{abstract}
An iron(II) clathrochelate having methylglyoxime rib fragment was treated with $\mathrm{Fe}(\mathrm{II}) / \mathrm{t}$-BuOOH in 1,4-dioxane. The reaction resulted in substitution of the aldoxime hydrogen with 1,4-dioxanyl fragment by virtue of Minisci reaction mechanism. The resultant cage complex was identified with single crystal $X R D$, mass-spectrometry, ${ }^{1} \mathrm{H},{ }^{13} \mathrm{C},{ }^{19} \mathrm{~F},{ }^{11} \mathrm{~B} N \mathrm{NMR}$ spectroscopy, and examined with UV-Vis and IR spectroscopy. This reaction extends the range of synthetic approaches applicable for the functionalization of tris-dioximate cage complexes.
\end{abstract}

Keywords: Clathrochelate, iron(II), 1,4-dioxane, Minisci reaction, X-ray crystallography, multinuclear NMR.

\section{Применение реакции Миниши Аля модификации трис-Аиоксиматных клатрохелатов металлов: свободно-радикальное замещение в глиоксиматном фрагменте клетки, инкапсулирующей железо(II)}

\author{
А. Б. Бурдуков, ${ }^{a} @$ М. А. Вершинин, ${ }^{a}$ Н. В. Первухина, ${ }^{a}$ Н. В. Куратьева, ${ }^{a}$ \\ И. В. Ельцов, ${ }^{\text {b }}$ А. С. Белов, ${ }^{c}$ Я. З. Волошин, ${ }^{c}$ А. А. Нефедов \\ ${ }^{\mathrm{a}}$ Институт неорганической химии им. А.В. Николаева СО РАН, 630090 Новосибирск, Россия \\ ${ }^{\mathrm{b}}$ Новосибирский государственный университет, 630090 Новосибирск, Россия \\ ${ }^{\mathrm{c}}$ Институт элементоорганических соединений им. А. Н. Несмеянова, 119991 Москва, Россия \\ ${ }^{\mathrm{d}}$ Новосибирский институт органической химии СО РАН им. Н.Н. Ворожцова СО РАН, 630090 Новосибирск, Россия \\ ${ }^{\circledR}$ E-mail:lscc@niic.nsc.ru
}

\begin{abstract}
Клатрохелат железа(II), имеющий метилглиоксиматный реберный фрагмент, был обработан $\mathrm{Fe}(\mathrm{II}) / \mathrm{t}$-BuOOH в 1,4-диоксане. В результате реакиии альдоксимный атом водорода был замещен на фрагмент 1,4-диоксана по механизму реакции Миниши. Образовавщийся клеточный комплекс был идентифицирован методами РСА, масс-спектрометрии, ЯМР на ядрах ${ }^{1} \mathrm{H},{ }^{13} \mathrm{C},{ }^{19} \mathrm{~F},{ }^{11} \mathrm{~B}$ и изучен методами электронной и ИК-спектроскопии. Эта реакция расширяет диапазон синтетических подходов, доступных для функционализации трис-диоксиматных клеточных комплексов.
\end{abstract}

Ключевые слова: Клатрохелат, железо(II), 1,4-диоксан, реакция Миниши, РСА, ЯМР на различных ядрах. 


\section{Introduction}

For the first time, free-radical alkylation of electrondeficient aromatic compounds, which is also known as Minisci reaction, was reported in early 1970's. ${ }^{[1]}$ Initially based on an oxidative decarboxylation by persulfate dianion in presence of silver(I) cations as the radical source, further it has been extended to a variety of metal ions ${ }^{[2]}$ and to other radical sources ${ }^{[3-5]}$ as well. Different hydroperoxide $-\mathrm{Fe}^{2+}$ systems are also reported to be suitable to perform this radical reaction. ${ }^{[6,7]}$ Keeping in mind a pseudoaromatic character of the highly conjugated polyazomethine cage frameworks of the tris-dioximate metal clathrochelates and their electron-deficient nature stemming from the positive charge of the encapsulated metal ion, we aimed to apply the Minisci reaction for homolytic alkylation of these macrobicyclic substrates. Homolytic ribbed functionalization of the iron(II) cage tris-dioximates has been earlier performed using free radical substitution of the reactive chlorine atom of a dichloroclathrochelate precursor with carbon-centered radicals as shown in Scheme 1(i) ${ }^{[8-13]}$ and by free-radical reductive double alkylation of the methyl substituted azomethine group of the corresponding cage framework as well ${ }^{[14,15]}$ (Scheme 1,ii). Here we report the homolytic radical alkylation of a monomethylglyoximate iron(II) cage complex $\mathrm{FeBd}_{2} \mathrm{Mm}(\mathrm{BF})_{2}$ as a substrate under Minisci reaction conditions, as well as the detailed X-ray structural and spectral characterization of the macrobicyclic product of this reaction.

\section{Experimental}

1,4-Dioxane was purified from hydroperoxide by refluxing over $\mathrm{KOH}$ pellets and then dried by distillation over $\mathrm{P}_{2} \mathrm{O}_{5}$ and $\mathrm{CaH}_{2} \cdot{ }^{[16]}$ Commercial $5 \mathrm{M}$ decane solution of tert-butyl hydroperoxide (Sigma-Aldrich $(\mathbb{R})$ and other reagents, sorbents and solvents of the reagent grade were used without their additional purification.

${ }^{1} \mathrm{H},{ }^{13} \mathrm{C},{ }^{11} \mathrm{~B}$ and ${ }^{19} \mathrm{~F}$ NMR spectra were recorded using a Bruker Avance III 500 spectrometer (working frequencies $500.03\left({ }^{1} \mathrm{H}\right), 125.73\left({ }^{13} \mathrm{C}\right), 160.33\left({ }^{11} \mathrm{~B}\right)$ and $\left.470.49 \mathrm{MHz}\left({ }^{19} \mathrm{~F}\right)\right)$ from $\mathrm{CD}_{2} \mathrm{Cl}_{2}$ solution of the clathrochelate under study. ${ }^{1} \mathrm{H}$ and ${ }^{13} \mathrm{C}$ NMR chemical shifts are reported in ppm of the $\delta$ scale and were referred to the signals of this solvent $\delta_{\mathrm{H}}=5.34 \mathrm{ppm}$ for residual protons in ${ }^{1} \mathrm{H}$ NMR spectrum and $\delta_{\mathrm{C}}=53.80 \mathrm{ppm}$ in ${ }^{13} \mathrm{C}\left\{{ }^{1} \mathrm{H}\right\}$ NMR spectrum). ${ }^{11} \mathrm{~B}$ and ${ }^{19} \mathrm{~F}$ NMR chemical shifts were referred to the external standards $\mathrm{BF}_{3} \cdot \mathrm{O}\left(\mathrm{C}_{2} \mathrm{H}_{5}\right)_{2}\left(\delta_{\mathrm{B}}=0 \mathrm{ppm}\right)$ and $\mathrm{C}_{6} \mathrm{H}_{5} \mathrm{CF}_{3}$ $\left(\delta_{\mathrm{F}}=63.72 \mathrm{ppm}\right)$, respectively. Heteronuclear $\mathrm{C}-\mathrm{H}$ correlations (HMBC and HSQC) were applied for the assignment of NMR signals. ${ }^{1} \mathrm{H}-{ }^{1} \mathrm{H} J$-couplings and the positions of the signals of 1,4-dioxan-2-yl substituent were obtained and refined with spinsystem modeling NAMMRIT algorithm; the method of totallineshape fitting were used. All calculations were carried out using the Bruker Topspin v. 2.1 program package.

Low resolution mass-spectra and exact masses of the compound were obtained using Thermo Scientific Double Focusing System (DFS) high resolution mass-spectrometer. Samples were introduced into mass-spectrometer by direct inlet. The mass spectrometer used electron ionization with $70 \mathrm{eV}$ ionization energy.

$X$-Ray crystallography. Single crystals of the complex $\mathrm{FeBd}_{2}\left(\mathrm{CH}_{3}(\mathrm{Gm}(\mathrm{diox}))(\mathrm{BF})_{2} \cdot \mathrm{CH}_{2} \mathrm{Cl}_{2}\right.$, suitable for the X-ray diffraction experiment, were grown from its solution in heptane - dichloromethane mixture. The single crystal X-ray diffraction study of this complex was carried out with a Bruker Nonius X8 Apex diffractometer equipped with a $4 \mathrm{~K}$ CCD detector using graphite monochromated Mo-Ka radiation $(\lambda=0.71073 \AA)$ at $150 \mathrm{~K}$. Reflection intensities were integrated using SAINT software ${ }^{[17]}$ and corrected for absorption by a semi-empirical method (SADABS program ${ }^{[18]}$ ). The structure was solved by the direct method with SIR2014. ${ }^{[19]}$ All non-hydrogen atoms of the clathrochelate molecule were refined in anisotropic approximation against $\mathrm{F}^{2}$ with SHELX97 software. ${ }^{[20]}$ Hydrogen atoms of the dioxan-2-yl substituent were localized from Fourier synthesis and used to identify its carbon atoms. Further, all hydrogen atoms were set in their geometrical positions and included in the refinement using the riding model. The solvate dichloromethane molecule was disordered; and, thus, was refined isotropically without its hydrogen atoms.

Preparation of $\mathrm{FeBd}_{2} \mathrm{Mm}(\mathrm{BF})_{2}$ : 1,8-bis(2-fluorobora)-2,7,9, 14,15,20-hexaoxa-3,6,10,13,16,19-hexaaza-4,5,11,12-tetraphenyl17-methyl-bicyclo[6.6.6]eicosa-3,5,10,12,16,18-hexaeno(2-) iron (2+). Triethylamine $(2 \mathrm{ml}, 15 \mathrm{mmol})$ was added dropwise to the

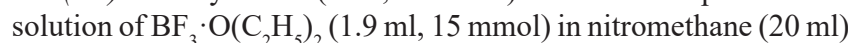
with intensive stirring under argon. Then hexamethyldisiloxane (0.2 ml, $1 \mathrm{mmol})$, methylglyoxime $(0.52 \mathrm{~g}, 5.1 \mathrm{mmol})$, complex $\left[\mathrm{FeBd}_{2}\left(\mathrm{BF}_{2}\right)_{2}\left(\mathrm{CH}_{3} \mathrm{CN}\right)_{2}\right](3.48 \mathrm{~g}, 4.9 \mathrm{mmol})$ and nitromethane $(10 \mathrm{ml})$ were added to the stirring reaction mixture. This mixture was heated to boiling, $\mathrm{BF}_{3} \cdot \mathrm{O}\left(\mathrm{C}_{2} \mathrm{H}_{5}\right)_{2}(0.6 \mathrm{ml}, 5 \mathrm{mmol})$ was added and the solvent $(23 \mathrm{ml})$ was partially distilled off for $1.5 \mathrm{~h}$ from the boiling reaction mixture (the reaction course was controlled by TLC; eluent: dichloromethane-hexane 1:2 mixture). Then this dark-red mixture was cooled to r.t., the precipitate formed was filtered off and washed with ethanol $(30 \mathrm{ml}$, in three portions), diethyl ether $(20 \mathrm{ml}$, in two portions), and hexane $(10 \mathrm{ml})$. The product was extracted with dichloromethane $(20 \mathrm{ml})$ and the extract was flash-chromatographed on silica gel $(30 \mathrm{~mm}$ layer; eluent: dichloromethane). The major red elute was filtered, evaporated to a small volume and precipitated with hexane. The precipitate was filtered off, washed with hexane and dried in vacuo. Yield: $2.23 \mathrm{~g}$ (66\%). ${ }^{1} \mathrm{H}$ NMR $\left(\mathrm{CD}_{2} \mathrm{Cl}_{2}\right) \delta$ ppm: 2.37 (s, 3H, Me), $7.26(\mathrm{~m}, 20 \mathrm{H}$, $\mathrm{Ph}), 7.82(\mathrm{~s}, 1 \mathrm{H}, \mathrm{HC}=\mathrm{N}) .{ }^{13} \mathrm{C}\left\{{ }^{1} \mathrm{H}\right\} \mathrm{NMR}\left(\mathrm{CD}_{2} \mathrm{Cl}_{2}\right) \delta \mathrm{ppm}: 14.10(\mathrm{~s}$, $\mathrm{Me}), 128.29,129.41,130.39,130.79($ all s, Ph), $145.98(\mathrm{~s}, \mathrm{HC}=\mathrm{N})$, $154.11(\mathrm{~s}, \mathrm{MeC}=\mathrm{N}), 156.09,156.40$ (both $\mathrm{s}, \mathrm{PhC}=\mathrm{N})$.

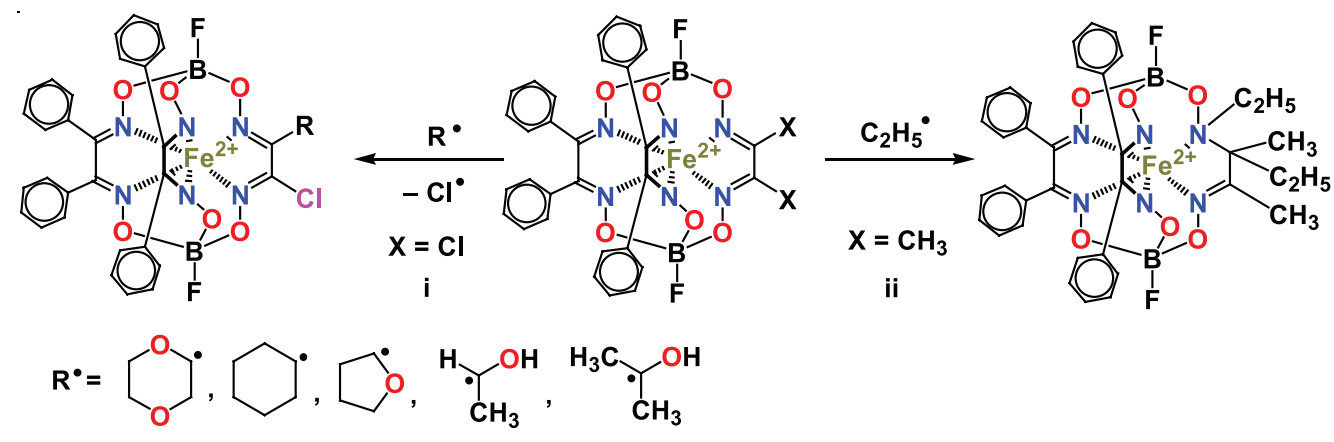

Scheme 1. 
Preparation of $\mathrm{FeBd}_{2}\left(\mathrm{CH}_{3} \mathrm{Gm}(\right.$ diox $\left.)\right)(\mathrm{BF})_{2}:$ 1,8-bis(2-fluorobora)-2, 7,9,14,15,20-hexaoxa-3, 6,10,13,16,19-hexaaza-4,5,11,12tetraphenyl-17-methyl-18-(1,4-dioxan-2-yl)bicyclo[6.6.6]eicosa3,5,10,12,16,18-hexaeno(2-) iron(2+). Complex FeBd $\left.\mathrm{Mm}_{(\mathrm{BF}}\right)_{2}$ $(0.123 \mathrm{~g}, 0.18 \mathrm{mmol})$ and $\mathrm{FeSO}_{4} \cdot 7 \mathrm{H}_{2} \mathrm{O}(0.108 \mathrm{~g}, 0.39 \mathrm{mmol})$ were dissolved/suspended in 1,4-dioxane $(20 \mathrm{ml}) .5 \mathrm{M}$ decane solution of tert-butyl hydroperoxide $(0.24 \mathrm{ml}, 1.2 \mathrm{mmol})$ was added and the reaction mixture was refluxed for $2.5 \mathrm{~h}$. Then this mixture was cooled to room temperature, filtered and evaporated to dryness in vacuo. The oily residue was chromatographically separated on silica gel (230-400 mesh, $1 \times 20 \mathrm{~cm}$ column, eluent: chloroform). The first minor elute, containing the clathrochelate precursor, was thrown out and the second elute was collected. This elute was evaporated to dryness, recrystallized from dichloromethane-heptane mixture $(2: 1 \mathrm{v} / \mathrm{v})$ and dried in vacuo. Yield: $0.047 \mathrm{~g}(34 \%)$. EIMS: $m / z$ Calcd. 778.1119; Found: 778.1671 (100\%); composition found: $\mathrm{C}_{35} \mathrm{H}_{30} \mathrm{O}_{8} \mathrm{~N}_{6}{ }_{6}^{11} \mathrm{~B}_{2} \mathrm{~F}_{2}{ }^{66} \mathrm{Fe}_{1}$, calcd: $\mathrm{C}_{35} \mathrm{H}_{30} \mathrm{O}_{8} \mathrm{~N}_{6} \mathrm{~B}_{2} \mathrm{~F}_{2} \mathrm{Fe} .{ }^{1} \mathrm{H} \mathrm{NMR}$ $\left(\mathrm{CD}_{2} \mathrm{Cl}_{2}\right) \delta$ ppm: $2.75(\mathrm{~s}, 3 \mathrm{H}, \mathrm{Me}), 3.69\left(\mathrm{dd}, 1 \mathrm{H}, 3-\mathrm{H}_{\text {diox }}\right), 3.79(\mathrm{dd}$, $\left.1 \mathrm{H}, 5-\mathrm{H}_{\text {diox }}\right), 3.83\left(\mathrm{dd}, 1 \mathrm{H}, 5-\mathrm{H}_{\text {diox }}\right), 3.91\left(\mathrm{td}, 1 \mathrm{H}, 6-\mathrm{H}_{\text {diox }}\right), 3.98(\mathrm{dd}$, $\left.1 \mathrm{H}, 6-\mathrm{H}_{\text {diox }}\right), 4.02\left(\mathrm{dd}, 1 \mathrm{H}, 3-\mathrm{H}_{\text {diox }}\right), 5.61\left(\mathrm{dd}, 1 \mathrm{H}, 2-\mathrm{H}_{\text {diox }}\right), 7.35(\mathrm{~m}$, $20 \mathrm{H}, \mathrm{Ph}) \cdot{ }^{13} \mathrm{C}\left\{{ }^{1} \mathrm{H}\right\}$ NMR $\left(\mathrm{CD}_{2} \mathrm{Cl}_{2}\right) \delta$ ppm: 15.40 (s, Me), 66.72 $\left(\mathrm{s}, 5-\mathrm{C}_{\text {diox }}\right), 67.41\left(\mathrm{~s}, 3-\mathrm{C}_{\text {diox }}\right), 67.68\left(\mathrm{~s}, 6-\mathrm{C}_{\text {diox }}\right), 72.90\left(\mathrm{~s}, 2-\mathrm{C}_{\text {diox }}\right)$, 128.40, 128.42 (two s, 3-Ph), 129.62, 129.64, 129.66 (all s, 1-Ph), $130.50,130,53$ (two s, 4-Ph), 130.94, 130.97, 131.00 (all s, 2-Ph), $155.47(\mathrm{~s}, \operatorname{dioxC}=\mathrm{N}), 156.30(\mathrm{~s}, \mathrm{MeC}=\mathrm{N}), 156.44,156.54,156.70$ (all s, $\mathrm{PhC}=\mathrm{N}) .{ }^{11} \mathrm{~B}$ NMR $\left(\mathrm{CD}_{2} \mathrm{Cl}_{2}\right) \delta \mathrm{ppm}\left(J_{11{ }_{\mathrm{B}-}{ }^{19} \mathrm{~F}}\right): 3.61,3.72$ (two d, $\left.16 \mathrm{~Hz}, \mathrm{O}_{3} \mathrm{BF}\right) .{ }^{19} \mathrm{~F}$ NMR $\left(\mathrm{CD}_{2} \mathrm{Cl}_{2}\right) \delta$ ppm: $-169.40,-169.48$ (two m, $\mathrm{O}_{3} \mathrm{BF}$ ). IR (KBr) $\vee \mathrm{cm}^{-1}: 694,777,939,1000 \mathrm{~m}, 1060$, $1110 v(\mathrm{~N}-\mathrm{O}), 1193 \mathrm{~m} v(\mathrm{~B}-\mathrm{O})+v(\mathrm{~B}-\mathrm{F}), 1545 v(\operatorname{diox} \mathrm{C}=\mathrm{N}), 1580$ $v(\mathrm{PhC}=\mathrm{N})+(\mathrm{MeC}=\mathrm{N}) . \mathrm{UV}-\mathrm{Vis} \lambda \mathrm{nm}\left(\varepsilon: 10^{-3}\right): 460(21), 490(9.5)$.

\section{Results and Discussion}

The monomethylglyoximate iron(II) clathrochelate $\mathrm{FeBd}_{2} \mathrm{Mm}(\mathrm{BF})_{2}{ }^{[21]}$ (where $\mathrm{Bd}^{2-}$ and $\mathrm{Mm}^{2-}$ are $\alpha$-benzildioxime and methylglyoxime dianions, respectively; refer to Experimental for enhanced synthetic protocol), with two unreactive $\alpha$-benzildioximate chelate fragments and one substantially more reactive (under conditions of the Minisci reaction) methylglyoximate ribbed moiety, was used as a macrobicyclic precursor (substrate). This allowed minimizing the number of the possible reactive sites of the substrate molecule and, thus, the range of the possible reaction products, as well as to compare the reactivity of its glyoximate (methine) oxime functional group and its methyl substituted analog. The Fenton-type $\mathrm{Fe}^{2+}$-tertbutylhydroperoxide system was chosen for in situ generation of the reactive primary tert-butoxyl radicals: ${ }^{[6]}$ they abstract hydrogen atom from 1,4-dioxane thus yielding the secondary 1,4-dioxan-2-yl radicals. These radicals further attack the glyoximate (methine) donor group of the macrobicyclic ligand, and the oxidation of the intermediate spin adduct by iron(III) ions completes this reaction (Scheme 2,i).

Mechanistically, the first stage of the above reaction is identical to that of the radical substitution of chlorine atom in a dichloroclathrochelate $\mathrm{FeBd}_{2}\left(\mathrm{Cl}_{2} \mathrm{Gm}\right)(\mathrm{BF})_{2}$ (where $\mathrm{Cl}_{2} \mathrm{Gm}^{2-}$ is dichloroglyoxime dianion) with 1,4-dioxan-2$\mathrm{yl}$ radical, ${ }^{[10]}$ whereas the destinies of their intermediate spin adducts are different. Indeed, the chlorine atom, being a good leaving group, detaches from this intermediate giving the clathrochelate product $\mathrm{FeBd}_{2}(\mathrm{ClGm}(\operatorname{diox}))(\mathrm{BF})_{2}$ (Scheme 2,ii). On the contrary, in accordance with the plausible Minisci reaction mechanism, ${ }^{[5]}$ the methine hydrogen atom, that is a much worse leaving group, undergoes oxidation with iron(III) thus leading to the alkylated clathrochelate product $\mathrm{FeBd}_{2}\left(\mathrm{CH}_{3} \mathrm{Gm}(\right.$ diox $\left.)\right)(\mathrm{BF})_{2}$ and $\mathrm{H}^{+}$.

General view of the molecule $\mathrm{FeBd}_{2}\left(\mathrm{CH}_{3} \mathrm{Gm}(\operatorname{diox})\right)(\mathrm{BF})_{2}$ (single crystal X-ray diffraction analysis, Table 1) is shown in Figure 1. The encapsulated iron(II) ion has a distorted trigonal-prismatic (TP) $\mathrm{FeN}_{6}$-coordination polyhedron, characteristic of this type of the iron(II) clathrochelates and its average distortion angle $\varphi$ is equal to $23.5^{\circ}\left(\varphi=0^{\circ}\right.$ for an ideal TP and $\varphi=60^{\circ}$ for an ideal trigonal antiprism (TAP)). The height $h$ of this polyhedron is approximately $2.33 \AA$ and the $\mathrm{Fe}-\mathrm{N}$ distances fall in the narrow range from 1.908 to $1.921 \AA$. Other main bond lengths and angles in the macrobicyclic framework and those in the rib 1,4-dioxan-2yl substituent have usual values. ${ }^{[22,23]}$ This substituent adopts

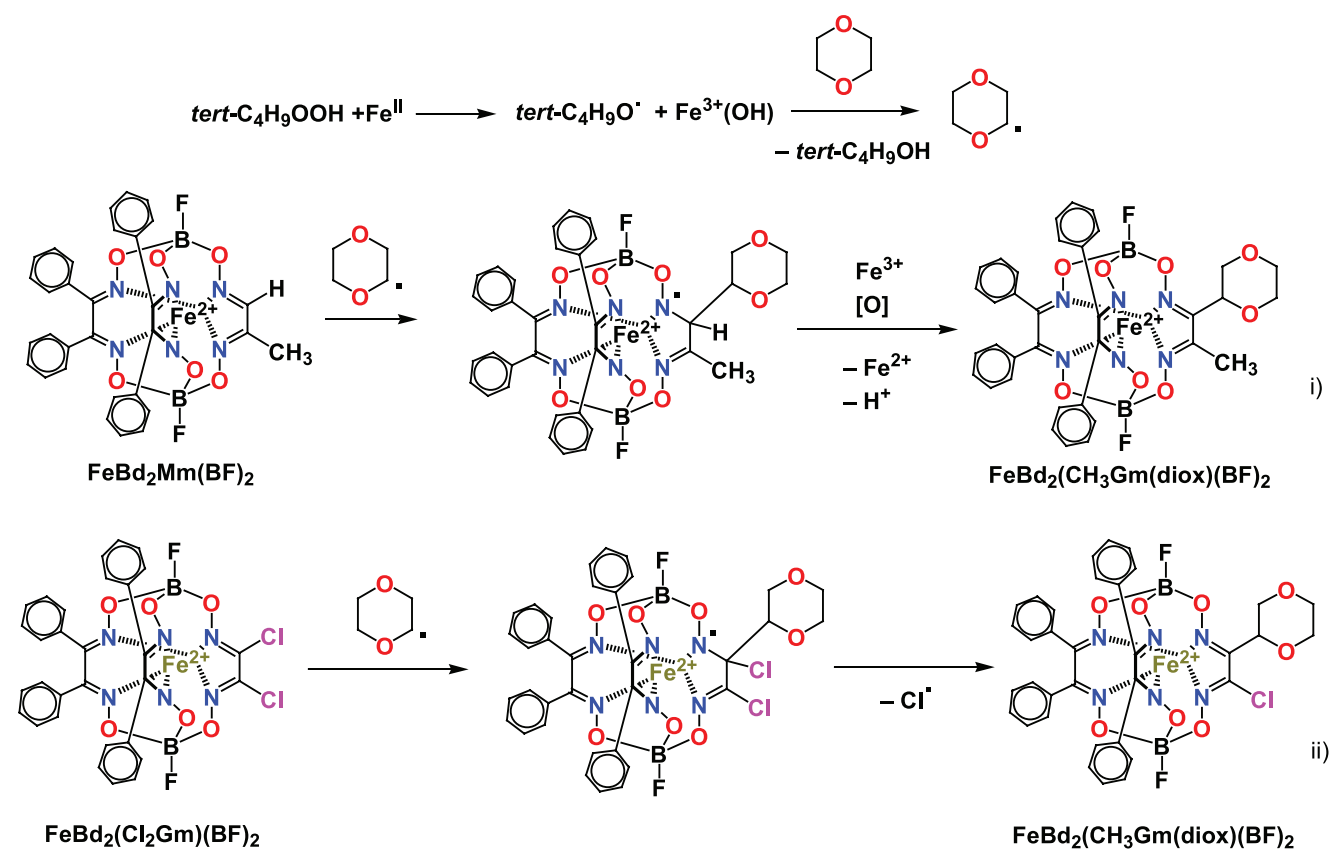

Scheme 2. 


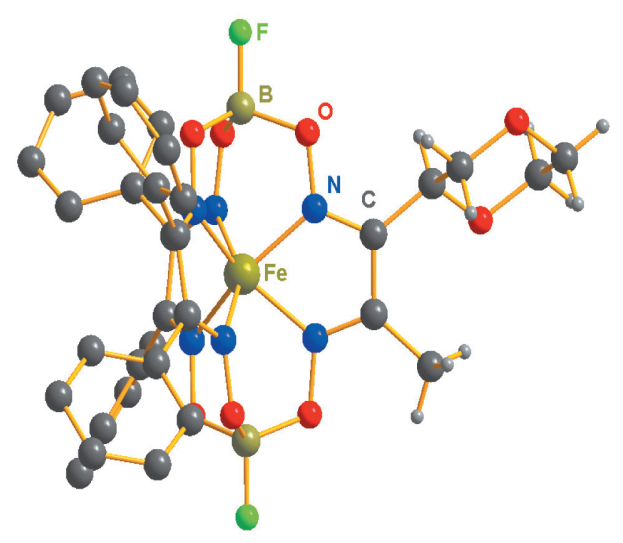

Figure 1. General view of the molecule $\mathrm{FeBd}_{2}\left(\mathrm{CH}_{3} \mathrm{Gm}(\mathrm{diox})\right)(\mathrm{BF})_{2}$. Hydrogen atoms of the phenyl substituents are omitted for clarity.

a common chair conformation showing no signatures of a static disorder; it has a chiral center at the carbon atom attached to the clathrochelate framework. As this cage complex crystallizes in the chiral space group $P 2{ }_{1} 2_{1} 2_{1}$, its crystal contains only one of the possible enantiomers.

It should be noted that all structurally characterized monosubstituted clathrochelates $\left.\mathrm{FeBd}_{2}(\mathrm{ClGmR})\right)(\mathrm{BF})_{2}$ (where $\mathrm{R}$ are 1,4-dioxan-2-yl, tetrahydrofuran-2-yl or 1,3-dioxolan-2-yl substituents) reported in literature ${ }^{[10,11,13]}$ and the clathrochelate under study are crystallized in this chiral space group, independently on the nature of a monofunctionalized cage molecule (i.e. is it chiral or not).

Multinuclear solution NMR study of the complex $\mathrm{FeBd}_{2}\left(\mathrm{CH}_{3} \mathrm{Gm}(\right.$ diox $\left.)\right)(\mathrm{BF})_{2}$ confirmed the identity of its molecular structure in solution and in solid state, while the above enantiomers of this clathrochelate, however, are indistinguishable by the NMR techniques applied. The complete assignment of the NMR signals for the molecule $\mathrm{FeBd}_{2}\left(\mathrm{CH}_{3} \mathrm{Gm}(\right.$ diox $\left.)\right)(\mathrm{BF})_{2}$ is given in Figure 2. Proton coupling constants and NMR shifts for the dioxanyl substituent are given in Table 2.

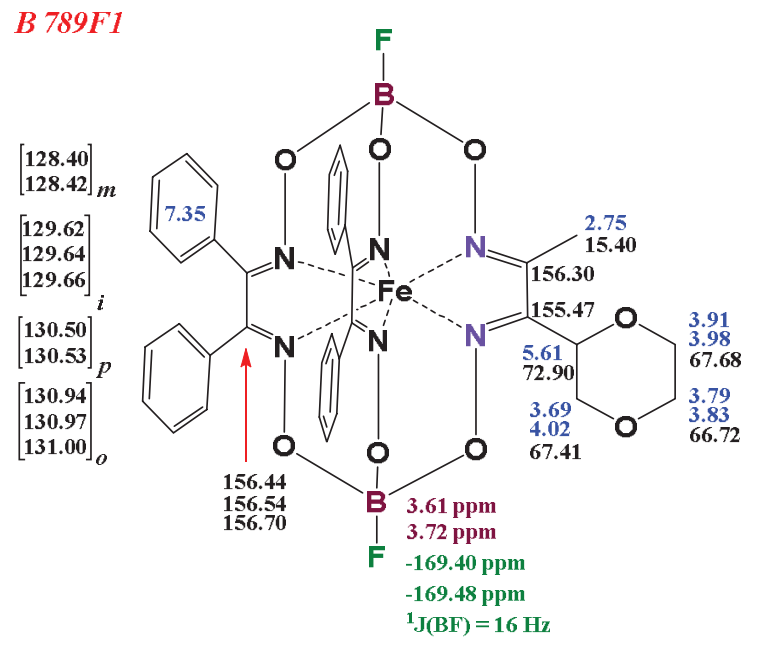

Figure 2. Assignment of the NMR signals for the molecule $\mathrm{FeBd}_{2}\left(\mathrm{CH}_{3} \mathrm{Gm}(\right.$ diox $\left.)\right)(\mathrm{BF})_{2}$.
Table 1. Crystallographic data and refinement parameters for the complex $\mathrm{FeBd}_{2}\left(\mathrm{CH}_{3} \mathrm{Gm}(\right.$ diox $\left.)\right)(\mathrm{BF})_{2} \cdot \mathrm{CH}_{2} \mathrm{Cl}_{2}$.

\begin{tabular}{|c|c|}
\hline & $\mathrm{FeBd}_{2}\left(\mathrm{CH}_{3} \mathrm{Gm}(\right.$ diox $\left.)\right)(\mathrm{BF})_{2} \cdot \mathrm{CH}_{2} \mathrm{Cl}_{2}$ \\
\hline Empirical formula & $\mathrm{C}_{36} \mathrm{H}_{30} \mathrm{~B}_{2} \mathrm{Cl}_{2} \mathrm{~F}_{2} \mathrm{FeN}_{6} \mathrm{O}_{8}$ \\
\hline Formula weight & 861.03 \\
\hline Crystal system & Orthorhombic \\
\hline Space group & $P 22_{1} 2_{1}$ \\
\hline$a(\AA)$ & $12.7423(4)$ \\
\hline$b(\AA)$ & $16.5899(5)$ \\
\hline$c(\AA)$ & $17.7248(5)$ \\
\hline $\mathrm{V}\left(\AA^{3}\right)$ & $3746.9(2)$ \\
\hline Z & 4 \\
\hline $\mathrm{d}_{\text {calc }}\left(\mathrm{g} / \mathrm{cm}^{3}\right)$ & 1.526 \\
\hline$\mu\left(\mathrm{mm}^{-1}\right)$ & 0.616 \\
\hline $\mathrm{F}(000)$ & 1760 \\
\hline Crystal size (mm) & $0.28 \times 0.20 \times 0.14$ \\
\hline $\begin{array}{l}\text { Theta range for data } \\
\text { collection }\end{array}$ & $2.02-27.53^{\circ}$ \\
\hline Index limits & $-16 \leq \mathrm{h} \leq 15,-21 \leq \mathrm{k} \leq 21,-15 \leq 1 \leq 22$ \\
\hline Reflections collected & 27711 \\
\hline Independent reflections $\left(R_{\text {int }}\right)$ & $8611(0.0435)$ \\
\hline Completeness to theta & $99.9 \%\left(25.25^{\circ}\right)$ \\
\hline Max. and min. transmission & 0.917 and 0.863 \\
\hline Data/restraints/parameters & $8611 / 0 / 503$ \\
\hline Goodness-of-fit on $F^{2}$ & 1.054 \\
\hline Final $R$ indices $\left(I>2 \sigma_{Y}\right)$ & $R_{1}=0.0562, w R_{2}=0.1403$ \\
\hline $\mathrm{R}$ indices (all data) & $R_{1}=0.0633, w R_{2}=0.1442$ \\
\hline Flack parameter & $0.04(2)$ \\
\hline $\begin{array}{l}\text { Largest diff. peak and hole } \\
\left(\mathrm{e} \cdot \AA^{-3}\right)\end{array}$ & 1.156 and -1.505 \\
\hline $\mathrm{CCDC}$ & 1497026 \\
\hline
\end{tabular}

Table 2. ${ }^{1} \mathrm{H}-{ }^{1} \mathrm{H} J$-couplings and the positions of the ${ }^{1} \mathrm{H}$ NMR signals of 1,4-dioxan-2-yl substituent in $\mathrm{FeBd}_{2}\left(\mathrm{CH}_{3} \mathrm{Gm}(\right.$ diox $\left.)\right)(\mathrm{BF})_{2}$ molecule.

\begin{tabular}{|c|c|c|c|c|c|c|c|}
\hline & $\mathrm{H} 3$ & H3' & H5 & $\mathrm{H} 5$, & H6 & H6' & $\delta_{\mathrm{H}}, \mathrm{ppm}$ \\
\hline $\mathrm{H} 2$ & 2.949 & 10.488 & & & & & 5.607 \\
\hline H3 & & 11.320 & & & & & 4.016 \\
\hline H3' & & & & & & & 3.687 \\
\hline H5 & & & & -11.76 & 0.818 & 2.717 & 3.828 \\
\hline H5 & & & & & 2.793 & 11.749 & 3.778 \\
\hline H6 & & & & & & -11.840 & 3.978 \\
\hline H6' & & & & & & & 3.914 \\
\hline
\end{tabular}

$\mathrm{UV}$-Vis spectra of the initial complex $\mathrm{FeBd}_{2} \mathrm{Mm}(\mathrm{BF})_{2}$ and the clathrochelate product $\mathrm{FeBd}_{2}\left(\mathrm{CH}_{3} \mathrm{Gm}(\right.$ diox $\left.)\right)(\mathrm{BF})_{2}$ in the visible range are very similar and contain the intensive bands assigned to metal-to-ligand charge transfer $\mathrm{Fed} \rightarrow L \pi *$. This similarity suggests that the above radical substitution of hydrogen atom by 1,4-dioxan-2-yl group only slightly affects the electronic structure of the quasiaromatic macrobicyclic framework of these cage complexes. 


\section{Conclusions}

Thus, we have shown that Minisci reaction can be successfully used for the rib functionalization of the trisdioximate metal clathrochelates containing aldoxime groups. This extends the range of synthetic approaches applicable for the direct functionalization of these cage complexes.

Acknowledgements. This work was partly supported by RFBR (grants 14-03-00384, 16-03-00408). Y.Z.V. also thanks the Russian Science Foundation (project 16-13-10475) for the financial support of the spectral part of this work.

\section{References}

1. Minisci F., Bernardi R., Bertini F., Gally R. Perchinummo M. Tetrahedron 1971, 27, 3575.

2. Minisci F., Citterio A. Acc. Chem. Res. 1983, 16, 27.

3. Minisci F., Vismara E., Fontana F. J. Org. Chem. 1989, 54, 5224.

4. Bolm C., Legros J., Le Paih J., Zani L. Chem. Rev. 2004, 104, 6217.

5. Li J.J. Name Reactions. A Collection of Detailed Mechanisms and Synthetic Applications, $5^{\text {th }}$ ed. Springer, Heidelberg, New York, Dordrecht, London, 2014. p. 403-404.

6. Correa A., Fiser B., Gómez-Bengoa E. Chem. Commun. 2015, $51,13365$.

7. Minisci F., Vismara E., Fontana F., Radaelli D. Gazz. Chim. Ital. 1987, 117(5), 363.

8. Burdukov A.B., Vershinin M.A., Pervukhina N.V., Kozlova S.G., Eltsov I.V., Voloshin Y.Z. Russ. Chem. Bull., Int. Ed. 2011, 60, 2504.
9. Vershinin M.A., Burdukov A.B., Pervukhina N.V., Eltsov I.V., Voloshin Y.Z. Inorg. Chem. Commun. 2013, 30, 159.

10. Vershinin M.A., Burdukov A.B., Eltsov I.V., Reznikov V.A., Boguslavsky E.G., Voloshin Y.Z. Polyhedron 2011, 30, 1233.

11. Vershinin M.A., Burdukov A.B., Pervukhina N.V., Eltsov I.V., Voloshin Y.Z. Macroheterocycles 2012, 5, 11.

12. Vershinin M.A., Burdukov A.B., Pervukhina N.V., Eltsov I.V. J. Struct. Chem. 2015, 56, 379.

13. Vershinin M.A., Burdukov A.B., Pervukhina N.V., Eltsov I.V., Voloshin Y.Z. Macroheterocycles 2015, 8, 71 .

14. Burdukov A.B., Vershinin M.A., Boguslavsky E.G., Eltsov I.V., Romanenko G.V., Belov A.S., Voloshin Y.Z. Inorg. Chem. Comm. 2013, 36, 117.

15. Burdukov A.B., Vershinin M.A., Pervukhina N.V., Eltsov I.V., Voloshin Y.Z. Curr. Inorg. Chem. 2015, 5, 71.

16. Armarego W.L.F., Chai C. Purification of Laboratory Chemicals, 6 ed, Oxford: Butterworth-Heinemann, 2009. 609 p.

17. SMART and SAINT, Release 5.0, Area detector control and integration software. Bruker AXS, Analytical X-Ray Instruments, Madison, Wisconsin, USA, 1998.

18. SADABS v.2.01, Bruker/Siemens Area Detector Absorption Correction Program, Bruker AXS, Madison, Wisconsin, USA, 1998.

19. Burla M.C., Caliandro R., Carrozzini B., Cascarano G.L., Cuocci C., Giacovazzo C., Mallamo M., Mazzone A., Polidori G. J. Appl. Cryst. 2015, 48, 306-309.

20. Sheldrick G.M., SHELX97 Release 97-2, University of Göttingen, Germany, 1998.

21. Voloshin Y.Z., Belov A.S., Starikova Z.A., Vologzhanina A.V. Russ. Chem. Bull., Int. Ed. 2013, 62, 1858.

22. Voloshin Y.Z., Antipin M.Yu. Russ. Chem. Bull., Int. Ed. 2004, 53, 2097.

23. Allen F.H., Kennard O., Watson D.G., Brammer L., Orphen A.G., Taylor R. Perkin Trans. II 1987, S1. 